\title{
Effect of Iron and Zinc Nutrition on Growth Attributes and Yield of Chickpea (Cicer arietinum $\mathrm{L}$.)
}

\author{
Kuldeep $^{1 *}$, P.D. Kumawat ${ }^{1}$, Vipen Bhadu ${ }^{1}$, H.K. Sumeriya ${ }^{2}$ and Vinod Kumar $^{2}$ \\ ${ }^{1}$ Department of Agronomy, College of Agriculture, Junagadh Agricultural University, \\ Junagadh-362 001, Gujarat, India \\ ${ }^{2}$ Department of Agronomy, Rajasthan College of Agriculture, Maharana Pratap University of \\ Agriculture and Technology, Udaipur-313 001, Rajasthan, India \\ *Corresponding author email
}

\section{A B S T R A C T}

Keywords

Chickpea, Iron,

Zinc, Growth and Yield

Article Info

Accepted:

xx July 2018

Available Online:

xx August 2018
An experiment was conducted to assess the effect of iron and zinc nutrition on growth attributes and yield of chickpea (Cicer arietinum L.) during 2014-15 at the Department of Agronomy, College of Agriculture, JAU, Junagadh. The results of experiment indicated that growth parameters viz., plant height, dry matter accumulation at 90 DAS and at harvest, branches per plant, number and dry weight of root nodules per plant increased significantly with the increase in iron levels up to $4.0 \mathrm{~kg} \mathrm{Fe} \mathrm{ha}^{-1}$ whereas significant response was obtained up to $6.0 \mathrm{~kg} \mathrm{Fe} \mathrm{ha}{ }^{-1}$ in dry matter accumulation at 60 DAS. Significant improvement in yield viz., seed, stover and biological yields was observed with the increasing levels of iron up to $4.0 \mathrm{~kg} \mathrm{Fe} \mathrm{ha}^{-1}$ over control and $2.0 \mathrm{~kg} \mathrm{Fe} \mathrm{ha}^{-1}$. Similarly zinc is also an essential plant nutrient for plant growth and yield. Zinc application had also positive effect on all growth attributes and yield parameters as per above mention are significantly increased with the levels of zinc up to $2.5 \mathrm{~kg} \mathrm{ha}^{-1}$.

\section{Introduction}

Chickpea is one of the major pulse crop grown during Rabi season. Chickpea, besides being a rich source of $\mathrm{Ca}, \mathrm{Fe}$, niacin, vitamin $\mathrm{B}$ and $\mathrm{C}$. Among the food crops, pulses are an important group which occupies a unique position in the world of agriculture by virtue of their high protein content (18-22 \%). Importance of pulses is relatively more in our country as its contribution in nutrient supply is far more in Indian diet than that in Asia and world as a whole. Chickpea is mostly consumed in the form of processed whole seed (boiled, roasted, parched, fried, steamed, sprouted etc.) or dal or as dal flour (besan). It is used in preparing a variety of snacks, sweets and condiments. It is mixed with wheat flour for "chapati" making. Fresh green seeds are consumed as green vegetable. Green leaves are used as vegetable. Grains are also used as vegetable (chhole). Husk and bits of dal are used as nutritious feed for animals. Chickpea can also be used as green fodder for animals. It is mainly grown in more than 50 countries including India, Pakistan, Turkey, Iran, Myanmar, Australia, Ethopia, Canada, Mexico and Iraq (Gaur et al., 2010). Chickpea is the third most 
important pulse crop in the world after beans and field peas. In India, it is the premier pulse crop occupying 10.2 million hectares area and contributing 9.9 million tonnes to the national pulse basket with the productivity of $967 \mathrm{~kg}$ ha $^{-1}$ (Anonymous, 2014-15). In Gujarat, chickpea occupied an area of 2.47 lakh hectares with a production of 3.10 lakh tonnes with the average yield of $1251 \mathrm{~kg} \mathrm{ha}^{-1}$ (Anonymous, 2014-15). Among all agronomic factors, adequate fertilization stands first and it is considered as one of the most productive inputs in agriculture. High fertilizer responsive new varieties with improved agronomic practices, can express full yield potential only when adequate quantities of micronutrients containing fertilizer are also applied along with NPK fertilizers (Singh and Tripathi, 1974). In modern agriculture micronutrients are becoming deficient day by day due to intensive cultivation with high yielding varieties of crops using high analysis fertilizers, which not only reduce the crop productivity but also deteriorates the quality of produce. Micronutrients are essential for the normal growth of plants. Deficiencies of micronutrient drastically affected the growth, metabolism and reproductive phase in plants, animals and human beings. Micronutrient malnutrition affects more than half of the world population particularly in the developing countries (Alloway, 2008) and in particular $\mathrm{Fe}$ and $\mathrm{Zn}$ deficiency in human nutrition are wide-spread in developing Asian countries including India. Iron plays an important role in chlorophyll synthesis, being a structural component of hemes, hematin and leg hemoglobin. And it is also an important part of the enzyme nitrogenase, which is essential for the $\mathrm{N}_{2}$ fixation in legumes. The agronomic importance of chickpea is linked to its high protein content and other essential minerals, especially micronutrients. About $49 \%$ of Indian soils are deficient in zinc and response to $\mathrm{Zn}$ application has been reported for a number of crops including chickpea.
Zinc plays an important role in formation of chlorophyll and growth hormones. Zinc is also an essential plant nutrient for plant growth and development. $\mathrm{Zn}$ is recognized as essential component of several enzyme systems having vital roles in the plant metabolism, e.g. carbonic anhydrase for reversible hydration of $\mathrm{CO}_{2}$ to form $\mathrm{HCO}_{3}^{-}$for transport and utilization of $\mathrm{CO}_{2}$ in photosynthesis. It is also responsible for resisting $\mathrm{pH}$ changes in cytoplasm. $\mathrm{Zn}$ is involved in auxin metabolism like, tryptophan synthesis, tryptamine metabolism. Therefore, the present investigation was carried out to study the effect of $\mathrm{Fe}$ and $\mathrm{Zn}$ nutrition on growth and yield of chickpea.

\section{Materials and Methods}

The field experiment entitled "effect of iron and zinc nutrition on growth attribute and yield of chickpea (Cicer arietinum L.)" was conducted during the year 2014-15 at Instructional Farm, Department of Agronomy, Junagadh Agricultural University, Junagadh (Gujarat), which is situated in South Saurashtra Agro-climatic region of Gujarat state and enjoys a typically subtropical climate characterized by fairly cold and dry winter, hot and dry summer as well as warm and moderately humid monsoon. Which is situated at $21.5^{\circ} \mathrm{N}$ latitude and $70.5^{\circ} \mathrm{E}$ longitudes with an altitude of $60 \mathrm{~m}$ above the mean sea level. The soil was clayey in texture and slightly alkaline in reaction with $\mathrm{pH} 7.8$ and EC 0.33 $\mathrm{dS} \mathrm{m} \mathrm{m}^{-1}$. The soil of the experimental site was medium in available iron $\left(5.23 \mathrm{mg} \mathrm{kg}^{-1}\right)$ and zinc $\left(0.75 \mathrm{mg} \mathrm{kg}^{-1}\right)$ and low in sulphur $(17.02$ $\left.\mathrm{kg} \mathrm{ha}^{-1}\right)$. Total sixteen treatment combinations involving four levels of iron $(0,2.00,4.00$ and $\left.6.00 \mathrm{Kg} \mathrm{ha}^{-1}\right)$ and four levels of zinc $(0,1.25$, 2.50 and $5.00 \mathrm{Kg} \mathrm{ha}^{-1}$ ) were tested in a factorial randomized block design (FRBD) with three repetitions. The crop was sown in $45 \mathrm{~cm} \times 10 \mathrm{~cm}$ spacing with seed rate of 60 $\mathrm{kg} / \mathrm{ha}$. The variety GG-1 was sown on $16^{\text {th }}$ 
November and recommended dose of fertilizer was 20-40-0 N-P-K $\mathrm{kg} \mathrm{ha}^{-1}$ and all other recommended practices were adopted according to as per needed of crop requirement. Statistical analysis of the individual data of various characters studied in the experiment was carried out using standard statistical procedures as described by Panse and Sukhatme (1985). Standard error of mean, critical difference (C.D.) at 5 per cent level of probability and coefficient of variance were worked out for the interpretation of the results.

\section{Results and Discussion}

\section{Iron}

It is apparent from data in Table 1. indicated that the increasing levels of iron significantly increased the dry matter accumulation at different stages viz. 90 DAS and at harvest, plant height at harvest, number of branches per plant, number of root nodules per plant at 45 DAS, dry weight of root nodules per plant at 45 DAS as well as seed, stover and biological yield increased significantly up to
$4.0 \mathrm{~kg} \mathrm{Fe} \mathrm{ha}{ }^{-1}$ where as dry matter accumulation at 60 DAS increased significantly up to $6.0 \mathrm{~kg} \mathrm{Fe} \mathrm{ha}^{-1}$ (Table 2). Application of $6.0 \mathrm{~kg} \mathrm{Fe} \mathrm{ha}^{-1}$ registering 38.62 and 21.87 per cent higher in dry matter accumulation at harvest, 17.51 and 9.40 in plant height, 39.17 and 29.58 in seed yield, 27.94 and 22.16 in stover yield and 31.94 and 24.84 per cent in biological yield over control and $2.0 \mathrm{~kg} \mathrm{ha}^{-1}$ respectively.

This might be due to its role in starch formation and protein synthesis as well as maintenance and synthesis of chlorophyll in plants. The increase in the availability of iron to plant might have stimulated the metabolic and enzymatic activities thereby increasing the growth of the crop. Similar findings were also reported by Trivedi et al., (2011). The application of iron significantly increased the yield characteristics in chickpea. The yield of crop is the cumulative effect of growth attributing characters and yield characters such as pods per plant. These findings are in confirmation to the earlier reported by Kumar et al., (2009) and Khan et al., (2014).

Table.1 Effect of iron and zinc levels on growth and yield parameters of chickpea

\begin{tabular}{|c|c|c|c|c|c|c|c|}
\hline \multirow[t]{3}{*}{ Treatments } & \multicolumn{3}{|c|}{ Dry matter accumulation (g plant ${ }^{-1}$ ) } & \multirow{3}{*}{$\begin{array}{c}\text { Plant } \\
\text { height } \\
(\mathbf{c m})\end{array}$} & \multirow{3}{*}{$\begin{array}{l}\text { Branches } \\
\text { per plant }\end{array}$} & \multirow{2}{*}{\multicolumn{2}{|c|}{$\begin{array}{c}\text { Root nodules per plant } \\
\text { at } 45 \text { DAS }\end{array}$}} \\
\hline & \multirow[t]{2}{*}{60 DAS } & \multirow{2}{*}{$\begin{array}{c}90 \\
\text { DAS }\end{array}$} & \multirow[t]{2}{*}{ At harvest } & & & & \\
\hline & & & & & & Number & $\begin{array}{l}\text { Dry weight } \\
\left(\mathrm{mg} \mathrm{plant}^{-1}\right)\end{array}$ \\
\hline \multicolumn{8}{|l|}{ Iron $\left(\mathrm{kg} \mathrm{ha}^{-1}\right)$} \\
\hline 0.00 & 13.51 & 23.37 & 24.80 & 32.78 & 6.68 & 7.30 & 92.35 \\
\hline 2.00 & 15.15 & 26.52 & 28.21 & 35.21 & 7.50 & 7.80 & 100.34 \\
\hline 4.00 & 16.33 & 31.20 & 32.40 & 38.20 & 8.48 & 8.23 & 111.23 \\
\hline 6.00 & 18.23 & 33.97 & 34.38 & 38.52 & 8.62 & 8.48 & 114.07 \\
\hline SEm \pm & 0.43 & 0.93 & 0.94 & 0.73 & 0.23 & 0.23 & 2.55 \\
\hline $\mathrm{CD}(\mathrm{P}=0.05)$ & 1.24 & 2.69 & 2.71 & 2.12 & 0.66 & 0.65 & 7.37 \\
\hline \multicolumn{8}{|l|}{ Zinc $\left(\mathrm{kg} \mathrm{ha}^{-1}\right)$} \\
\hline 0.00 & 14.13 & 24.65 & 25.34 & 31.78 & 7.08 & 6.70 & 90.56 \\
\hline 1.25 & 15.04 & 27.42 & 28.80 & 35.46 & 7.57 & 7.66 & 101.53 \\
\hline 2.50 & 16.57 & 30.76 & 31.70 & 38.25 & 8.27 & 8.50 & 110.64 \\
\hline 5.00 & 17.48 & 32.23 & 33.95 & 39.23 & 8.37 & 8.95 & 115.27 \\
\hline SEm \pm & 0.43 & 0.93 & 0.94 & 0.73 & 0.23 & 0.23 & 2.55 \\
\hline $\mathrm{CD}(P=0.05)$ & 1.24 & 2.69 & 2.71 & 2.12 & 0.66 & 0.65 & 7.37 \\
\hline $\mathrm{CV}(\%)$ & 9.43 & 11.21 & 10.85 & 7.02 & 10.16 & 9.87 & 8.47 \\
\hline
\end{tabular}


Table.2 Effect of iron and zinc levels on yield parameters and harvest index of chickpea

\begin{tabular}{|c|c|c|c|c|}
\hline \multirow[t]{2}{*}{ Treatments } & \multicolumn{4}{|c|}{ Yield $\left(\mathrm{kg} \mathrm{ha}^{-1}\right)$} \\
\hline & Seed & Stover & Biological & Harvest index (\%) \\
\hline \multicolumn{5}{|l|}{ Iron $\left(\mathrm{kg} \mathrm{ha}^{-1}\right)$} \\
\hline 0.00 & 1404 & 2538 & 3942 & 35.72 \\
\hline 2.00 & 1508 & 2658 & 4166 & 36.44 \\
\hline 4.00 & 1884 & 3125 & 5009 & 37.80 \\
\hline 6.00 & 1954 & 3247 & 5201 & 37.58 \\
\hline SEm \pm & 53 & 96 & 103 & 1.38 \\
\hline $\mathrm{CD}(\mathrm{P}=0.05)$ & 154 & 276 & 297 & NS \\
\hline \multicolumn{5}{|l|}{ Zinc $\left(\mathrm{kg} \mathrm{ha}^{-1}\right)$} \\
\hline 0.00 & 1466 & 2494 & 3960 & 37.13 \\
\hline 1.25 & 1605 & 2735 & 4340 & 36.62 \\
\hline 2.50 & 1779 & 3115 & 4894 & 36.47 \\
\hline 5.00 & 1899 & 3225 & 5124 & 37.33 \\
\hline SEm \pm & 53 & 96 & 103 & 1.38 \\
\hline$C D(P=0.05)$ & 154 & 276 & 297 & NS \\
\hline $\mathrm{CV}(\%)$ & 10.94 & 11.46 & 7.78 & 12.94 \\
\hline
\end{tabular}

\section{Zinc}

The perusal of data presented in Table 1 . revealed that the increasing levels of zinc increased significantly all growth parameters in chickpea viz. 90 DAS and at harvest, plant height at harvest, number of branches per plant, number of root nodules per plant at 45 DAS, dry weight of root nodules per plant at 45 DAS as well as seed, stover and biological yield increased significantly up to $2.5 \mathrm{~kg} \mathrm{Zn}$ $\mathrm{ha}^{-1}$ and remained at par with $5.0 \mathrm{~kg} \mathrm{Zn} \mathrm{ha}{ }^{-1}$.

The corresponding increases with application of $5.0 \mathrm{~kg} \mathrm{Zn} \mathrm{ha}{ }^{-1}$ was 33.98 and 17.88 per cent in dry matter accumulation at harvest, 23.44 and 10.63 in plant height, 29.54 and 18.32 in seed yield, 29.31 and 17.92 in stover yield and 29.39 and 18.06 per cent in biological yield over control and $1.25 \mathrm{~kg} \mathrm{Zn} \mathrm{ha}{ }^{-1}$, respectively (Table 2). Zinc plays a pivotal role in cellular growth, differentiation and metabolism which results in vigorous growth of plants and extensive root system leading to increased growth parameters. Similar results were also reported by Karwasra and Kumar (2007), Sharma and Abrol (2007) and Kharol et al., (2014).

On the basis of one year experimental data, it may be concluded that soil application of 4.0 $\mathrm{kg} \mathrm{Fe} \mathrm{ha}{ }^{-1}$ and $2.5 \mathrm{~kg} \mathrm{Zn} \mathrm{ha}^{-1}$ were found effective in improving the growth and yield of chickpea under irrigated conditions of South Saurashtra Agro-climatic zone.

\section{References}

Alloway, B. J. 2008. Micronutrients deficiencies in global crop production. Springer, New York, pp. 1-539.

Anonymous, 2014-15. Directorate of economics and statistics, Department of Agriculture and Co-operation, Ministry of Agriculture, Government of India, New Delhi. pp. A 24-26.

Gaur, P. M., Tripathi, S., Gowda, C. C. L., Ranga Rao, G. V., Sharma, H. C., Pandey, S. and Sharma, M. 2010. Chickpea seed production manual. 
ICRISAT, Patancheru (Andhra Pardesh).

Karwasra, R. S. and Kumar, A. 2007. Effect of zinc application on growth, biomass and nutrient uptake by chickpea in calcareous soils. Haryana Journal of Agronomy, 23 (1-2):111-112.

Khan, N., Tariq, M., Ullah, K., Muhammad, D., Khan, I., Rahatulaah, K., Ahmed, N. and Ahmed, S. 2014. Effect of molybdenum and iron on nodulation, nitrogen fixation and yield of chickpea genotypes (Cicer arietinum L.). Journal of Agriculture and Veterinary Science, 7(1): 63-79.

Kharol, S., Sharma, M., Purohit, H. S., Jain, H. K., Lal, M. and Sumeriya, H. K. 2014. Effect of sulphur and zinc nutrition on yield, quality and nutrient content and uptake by chickpea (Cicer arietinum L.) Environment and Ecology, 32(4): 1470-1474.

Kumar, V., Dwivedi, V. N. and Tiwari, D. D. 2009. Effect of phosphorus and iron on yield and mineral nutrition in chickpea. Annals of Plant and Soil Research, 11: 16-18.

Panse, V. G. and Sukhatme, P. V. 1985. Statistical Methods for Agricultural workers (Second edition), I.C.A.R., New Delhi.

Sharma, V. and Abrol, V. 2007. Effect of phosphorous and zinc application on yield and uptake of phosphorus and zinc by chickpea under rainfed conditions. Journal of Food Legumes, 20: 49-51.

Singh, D. V. and Tripathi, B. R. 1974. Effect of $\mathrm{N}, \mathrm{P}$ and $\mathrm{K}$ fertilization on the uptake of indigenous and applied zinc in wheat crop. Journal of Indian Society of Soil Science, 22: 244-248.

Trivedi, A. K., Hemantaranjan, A. and Pandey, S. K. 2011. Iron application may improve growth and yield of soybean. Indian Journal of plant Physiology, 16(3/4): 309-313.

\section{How to cite this article:}

Kuldeep, P.D. Kumawat, Vipen Bhadu, H.K. Sumeriya and Vinod Kumar. 2018. Effect of Iron and Zinc Nutrition on Growth Attributes and Yield of Chickpea (Cicer arietinum L.). Int.J.Curr.Microbiol.App.Sci. 7(08): 2837-2841. doi: https://doi.org/10.20546/ijcmas.2018.708.298 